\title{
'I gave them laws that were not good' (Ezk 20:25): A biblical model of complex subjectivity and the prospects of multi-ethnic contextual reading
}

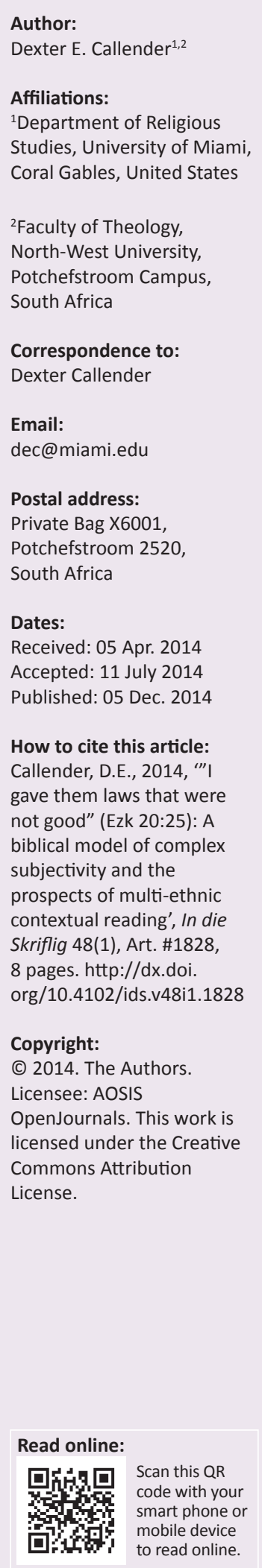

The purpose of this article is to address the problem of multi-cultural multi-ethnic contextual Bible reading by giving attention to identity and subjectivity and how it is modeled both in our analyses of contemporary life and in our reconstructions of antiquity and ancient contexts. The aim here is to suggest a position that engages the question of shared values; that creates a space for dialogue between contrasting discourses; and that gives attention to the question of authenticity. I suggest that resources for such a project may be found partly in a re-engaging of biblical prophecy in light of contemporary reflection on subjectivity that embraces recent developments in the debate over modern and postmodern approaches to language and experience tied to the rise of cognitive science. Through an examination of the subject in Žižek, particularly as he engages cognitive science, and in the prophetic rhetoric of Ezekiel, this article argues for grounding multi-group reading strategies or projects on a conception of complex subjectivity that seeks to bridge contemporary discourse with the language of the biblical text.

'Ek het vir hulle voorskrifte gegee wat nie goed was nie' (Eseg 20:25): 'n bybelse model van komplekse subjektiwiteit en die moontlikhede van multi-etniese kontekstuele interpretasie. Die oogmerk van hierdie artikel is om die probleem van 'n multi-kulturele, multi-etniese kontekstuele lees van die Bybel te ondersoek. Met dit ten doel, gee die ondersoek aandag aan identiteit en subjektiwiteit en hoe dit gedemonstreer word in die analise van die hedendaagse sowel as in die rekonstruksie van antikwiteite en antieke kontekste. Die uiteindelike doelwit is om 'n posisie voor te stel wat omgaan met die vraag van gedeelde waardes; wat ruimte skep vir 'n dialoog tussen teenstrydige diskoerse; en wat aandag gee aan die vraag van geloofwaardigheid. Die voorstel word gemaak dat 'n nuwe betrokkenheid by bybelse profesie in die lig van hedendaagse denke oor subjektiwiteit die hulpmiddele bied vir so ' $n$ poging. Hierdie nuwe denke verbind onlangse ontwikkelinge in die debat oor moderne en postmoderne benaderings tot taal en ervaring met die opkoms van die kognitiewe wetenskappe. Die artikel ondersoek die onderwerp soos deur Žižek voorgestel word, veral met betrekking tot hoe hy kognitiewe wetenskap bytrek, en soos dit in die profetiese retoriek van Esegiël beslag vind. Daaruit betoog die artikel vir 'n begronding van multi-groep leesstrategieë of -projekte in die gedagte van komplekse subjektiwiteit wat ten doel het om die hedendaagse diskoers met die taal van die bybelse teks te oorbrug.

\section{Introduction}

The Bible, as a source of values for society beyond the boundaries of self-identified faith communities, is a highly charged issue. Part of the reason stems from its own morally challenging texts. In Ezekiel 20:25-26, YHWH admits having given Israel laws that were 'not good'. Not surprisingly the general tendency amongst commentators has been to offer an explanation that rectifies the moral problem (Blenkinsopp 1990:90; Van der Horst 1992:94-118; Mein 2001:117-118). Read differently, however, the prophet's statement that God has deliberately given 'not good' laws problematises the idea of divine law as a fundamental ground of moral authority and raises questions of moral authority with respect to its source and form. The prophet's characterisation of both law and lawgiver activate the central problem of language in its relation to human experience. This article proposes a reading of the text based on recent perspectives in philosophy and cognitive science that approach identity and subjectivity in terms of language and the brain in ways that overcome the modern-postmodern divide. It proposes that the 'not good' laws are given in the context of divine law and idolatry in such a way that reframes the moral issue of unjust punishment, addressing it within a model of complex subjectivity. This has implications for strategies of reading across groups divided by different discursive 'worldviews' - both in terms of contextual hermeneutics as a theorised practice of the academy and for how the Bible in broader society is engaged. 
An introductory word is in order concerning the approach taken in this study. Any inquiry into the place of the Bible as a source of values properly includes within its subject reflection on the presuppositions upon which its claims are established. This involves examining the presuppositions that frame reading, theological orientations and worldviews; that is, how one understands self and self in relation to all else (society and the world), and the dynamics of power that surround these relations. Varieties of contextual hermeneutics have come into being and been established upon the need for such reflection. Their critiques have sought to redress uses of power by dominant groups and have done so by examining the ways identities are conceptualised through language use. Strategies of contextual reading both express and reinforce identity through the particular discourse of a community. Contextual reading is predicated upon reading framed by group-specific worldviews. Although these communities reflect the turn in recent decades from models of identity - of the self and community - predicated upon a Cartesian notion of self-contained subjectivity to models of subjectivity tied to language and discursive structures, recent attention to essentialism has highlighted the problems inherent in asserting the very 'identities' that constitute these groups.

R.S. Sugirtharajah, writing in the third edition of Voices from the Margin (2006) and reflecting on changes in the field in the 15 years that had transpired since the publication of the first edition, catalogues a host of challenges. Amongst these he cites the neglect of shared values arising from 'an obsessive focus on narrow identity issues' and the subsequent 'atomisation of the discipline and ... fragmentation of audiences and readership'; the challenge of contrasting discourses evident in liberation theology and postcolonial reflection; and the related challenge of the debate over authenticity, 'who speaks for whom and who is the new authentic voice' (Sugirtharajah 2006:4-6). The same holds true for biblical scholarship in its role mediating the use of the Bible in society. These challenges signal the need for establishing approaches capable of mediating the divergent voices that contextual hermeneutics claims by definition.

The work of Slovene philosopher, Slavoj Žižek, provides an opportunity to consider such an approach. The 'obsessive focus on narrow identity issues' in Sugirtharajah's critique of contextualbiblical hermeneutics reflects theover-commitment to particularity in postmodern political thought - one of Žižek's targets in The Ticklish Subject: The Absent Centre of Political Ontology (1999). The neglect of shared values, which Sugirtharajah sees in the atomisation of the discipline, echoes Žižek's critique of 'multiculturalist "identity polities"' and the notion that 'one should abandon the impossible goal of global social transformation and, instead, focus attention on the diverse forms of asserting one's particular subjectivity in our complex and dispersed postmodern universe, in which cultural recognition matters more than socioeconomic struggle' (Žižek 1999:xxvi). The problem, as Žižek sees it, is that the rejection of the 'Cartesian subject' that underlies such positions is based on a false choice between embodied self and disembodied subject (Johnston 2008:xxiii). Thus, his work aims to mediate the psyche-soma debate through 'productive cooperation' that brings cognitive science interested in the somatic, embodied aspect of self - into dialogue with philosophical and psychoanalytic approaches that emphasise the 'psychic' aspect of self that transcends the body (Johnston 2008:xxiv). Similar concerns have been addressed within contextual hermeneutics (see e.g. Rivera 2009:313-329). Žižek's method of reading holds promise for engaging biblical texts.

\section{Modeling subjectivity: Žižek and cognitive science}

Žižek's reframing of the Cartesian subject appropriates a major area of consensus amongst cognitive scientists who, through studies of cognitive impairment arising from brain injuries and perception experiments, view language and the brain in terms of parallel systems. Žižek invokes Daniel Dennett's metaphor for the human mind as 'a multitude of vaguely coordinated "softwares"', regarding which 'we find neither isolated particular organs with clearly defined functions, nor a universal Master-Self coordinating between them, but a permanently shifting "improvised" coordination [in which] one particular program (not always the same) can temporarily assume the coordinating function' (Žižek 1998:254). On this account, the mind is a 'pandemonium of competing forces' (Žižek 1998:254).

Dennett's Multiple Drafts model uses experiments on the phi phenomenon to demonstrate how subjective experience does not pertain to a realm of phenomena to which the subject has direct access. What we take to be our experience in the moment has actually already been (and is continuously being) rewritten and revised according to an ongoing stream of judgments made by parallel brain processes that, together, drive us to recognise ideal patterns (Žižek 1998:250-251; Dennett 1991:111-115). The 'content' of self-experience comprises traces of 'narrativised' memory. As Dennett (1991) puts it:

'Writing it down' in memory [is] criterial for consciousness; that is, what it is for the 'given' to be 'taken' - to be taken one way rather than another. There is no reality of conscious experience independent of the effects of various vehicles of content on subsequent action (and hence, on memory). (p. 132)

Žižek renders Dennett's Multiple Drafts model of the experience of self-consciousness in Hegelian terms: 'immediacy itself is mediated, it is a product of the mediation of traces' (Žižek 1998:250). Through Lacan, Žižek (1998) recasts the subject in negative terms:

The (Lacanian) subject of the unconscious is thus neither the standard (anti-) philosophical subject of self-awareness, nor the dispersed multitude of fluxes that explode the subject's unity: this opposition between the 'unified' subject of self-awareness and the dispersed pre-subjective multitude is false, it relies on the exclusion of the subject [as] the 'vanishing mediator' between the two (p. 266). 
Dennett's account of the self as the center of narrative gravity has a deconstructionist quality that he himself recognises as strikingly similar to David Lodge's 'semiotic materialism', in which 'there is only production, and we produce our "selves" in language'. For Dennett, who approvingly cites Lodge's appropriation of Derrida's dictum 'there is nothing outside the text', the place of language looms large. Noticing the surprising lack of attention contemporary linguists have given to language production, that is, to speaking as opposed to hearing, Dennett observes how studies of pathological conditions suggest that what we consider intentional and rational speech acts are not 'rational in the narrower sense', that is, they do not arise from serial reasoning (Dennett 1991:252). On one level, humans use language to reproduce themselves, but more fundamentally 'language uses humans to replicate itself' - a shift in perspective that Žižek reformulates in Hegelian terms as 'the shift from individuals to their social substance, as the Ground that reduces them to its accidents' (Žižek 1998:254).

Thus, Dennett's 'semiotic materialist' narrative of self resonates with Žižek's Lacanian approach to subjectivity, in which 'the big Other' denotes the symbolic order, specifically as an invading foreign presence that constitutes us as human subjects and, in doing so, forever alienates us from the Real. In the article, 'How the Non-Duped Err', Žižek (1990) focuses on the field of truth and deception that confronts the alienated subject in the big Other. Žižek uses narrative themes in several Hitchcock films to illustrate 'the radical externality of the Other as the place where the truth of the subject is articulated, echoing Lacan's thesis that "the unconscious is outside"'. This externality he points out 'is usually conceived as the external, non-psychological character of the formal symbolic structure regulating the subject's intimate selfexperience'. However, as Žižek (1990) goes on to assert:

[...] the (Hitchcockian and at the same time Lacanian) big Other is not simply a universal formal structure filled out with contingent imaginary contents (as with Levi-Strauss, where the symbolic order is equivalent to universal symbolic laws structuring the material of myths, kinship-relations, etc.). It is, on the contrary already at work where we encounter the eruption of what seems to be the purest subjective contingency. (p. 6)

Žižek characterises this eruption of subjective contingency in terms of Jon Elster's subversion of the idea of rational choice in what he calls 'states that are essentially by-products' (Elster 1983:43-109), summed up by Žižek (1990:6) as 'an innermost emotion that cannot be planned in advance or assumed by means of a conscious decision'. Such states, Žižek (1990:7) explains, 'are essentially produced by the big Other'. The big Other 'designates precisely the agency which decided instead of us, in the place of us' (Žižek 1990:7). Žižek identifies other figurations of the Lacanian big Other in Hegel's Reason of History and Adam Smith's 'invisible hand of the market' (Žižek 1990:7). At the same time, following the dictum of the later Lacan, Žižek (1990) cautions that 'the big Other doesn't exist':

[...] the big Other doesn't exist as Subject of History, given in advance and regulating our activity in a teleological way, using it as a means for its hidden aims - teleology is always a retroactive illusion, 'states that are essentially by-products' are radically contingent. (p. 8).

In this sense, the symbolic order is 'the place in which truth is determined and which as such "runs the game"' (Žižek 1990:1). It is the site of the formation of the subject and its experiences.

\section{'Laws that were not good': Prophecy and moral authority}

Žižek's engagement of Dennett provides a useful heuristic frame through which to consider Ezekiel's oracle revealing that $\mathrm{YHWH}$ had given laws to the people that were 'not good'. We read in Ezekiel 20:

Moreover I gave them statutes that were not good and ordinances by which they could not live. I defiled them through their very gifts, in their offering up all their firstborn, in order that I might horrify them, so that they might know that I am YHWH. (v. 25-26) ${ }^{1}$

Commentators have long noted the strange nature of this statement. ${ }^{2}$ Corrine Patton (1996:73-90) considers the bad laws to embody the whole of the legal tradition given in the wilderness in anticipation of the legislation of Ezekiel 40-48. Scott Hahn and John Bergsma (2004:217-218) suggest that Ezekiel, the priest, is offering a critique from a priestly perspective and that the 'not good' laws refer specifically to the Deuteronomic code. Many commentators consider the bad laws a reference to child sacrifice, mentioned in verse $26 .{ }^{3}$ In what follows, this article will consider several key structural features in the text before going on to observations in light of Žižek's Hegelian, Lacanian reading of Dennett. ${ }^{4}$

\section{Ezekiel 20:1-31: Overview of key structures and themes}

In assessing Ezekiel's problematic laws, four observations seem particularly relevant. The bad laws are a part of the answer to an unanswered inquiry. The answer is a twogeneration history that reveals a binary opposition of the statutes and ordinances of idolatry and the statutes and ordinances of the dispensation at Sinai. Further, the history in the oracle collapses time. Finally, the structure of the oracle places the 'not good' statutes in relation to all previous 'legislation' in a way that establishes a fine line between 'idolatrous' statutes and ordinances and 'divine' statutes and ordinances.

1.The New Revised Standard Version (NRSV; modified) will be used for all translations in this article.

2.Zimmerli (1979:411), for example, observes, 'the statement that Yahweh makes his law, which is otherwise celebrated as light (Ps 119:105) and a way of life, ... the occasion of punishment is quite unique in the Old Testament'.

3.All references indicating only the verse or verses, refer to Ezekiel 20.

4.On the various suggestions regarding the structure of Ezekiel 20, see for example Greenberg (1983:376-388); Allen (1990:5-8); Block (1997:611-617); Rom Shilon (2005:199-201); Mol (2009:87-110). 


\section{'Not good' law and unanswered inquiry}

Firstly, the context of Ezekiel's reference to bad laws is an inquiry of YHWH that goes unanswered (v. 1-31). The elders approach Ezekiel to inquire of $\mathrm{YHWH}$, who in turn refuses to be consulted and instructs the prophet to recount the 'abominations (תועבת) of their ancestors' (v. 1-4). In what follows (v. 5-31) Ezekiel recounts Israel's history of rebelliousness from the revelation of the name in Egypt (v. 5-9) and departure from Egypt (v. 10-17) to the second generation in the wilderness (v. 18-26) up to the present day (v. 27-31). ${ }^{5}$ The structure of the oracle draws attention to prophetic revelation by placing the history within an explicit literary frame of YHWH's refusal to be consulted: 'Thus says the Lord GOD: Why are you coming? To consult me? As I live, says the Lord GOD, I will not be consulted by you' (v. 3), and 'And shall I be consulted by you, O house of Israel? As I live, says the Lord GOD, I will not be consulted by you' (v. 31).

The notion of failed consultation appears elsewhere in Ezekiel 7 and 14, reflecting a fairly widespread motif (Greenberg 1983:155-156, 251-255).

\section{'Statutes and ordinances'}

Secondly, the laws are implicated in a history of responses to revelation that pits idolatry against the Sinai law, and in which they stand as its culmination. The history progresses through recursions of encounter-response-punishment, leading eventually to the shocking revelation of verses $25-26 .{ }^{6}$ The oracle reveals in two generations a binary opposition between idolatry and the life-giving laws of Sinai, according to which each generation is enjoined to avoid idolatry and is given a positive expression of divine law that alludes to the law revealed at Sinai, equated with life. Moreover, the history underscores this binary logic by recounting how each generation's failure to observe YHWH's laws equated with life is tantamount to idolatry and places them under the threat of death.

Each generation receives a command proscribing idolatry, followed by the declaration of the divine name. The first generation in Egypt is commanded to avoid idolatry in the two-part statement 'Cast away, each of you, the detestable things before your eyes' and 'Do not defile yourselves with the idols (גלולי) of Egypt. I am YHWH your God' (v. 7). The declaration of the divine name casts the statement within a covenantal frame. A similar commandment is issued to the second generation in the wilderness, also followed by the declaration of the divine name: 'Do not follow the statutes of your parents, nor observe their ordinances' and '[do not] defile yourselves with their idols (גלוליהם). I YHWH am your God' (v. 18-19a).

\section{On the divisions see Block (1997:639-641).}

6.Allen (1992:468) characterises this as: 'history repeating itself and finally turning into a grim, destructive parody of the repetition'.
Set in opposition to the commandments proscribing idolatry are allusions to the law revealed at Sinai, equated with life and expressed in the terms my statutes (חקקותי), my ordinances (משפטי), and my Sabbaths. Of the first generation, now in the wilderness, YHWH declares, 'I gave them my statutes and my ordinances, by whose observance everyone shall live' and 'I gave them my Sabbaths as a sign between me and them' (v. 11-12). The second generation receives what appears to be a restatement of the Sinai revelation in the words 'Follow my statutes and be careful to observe my ordinances, and hallow my Sabbaths that they may be a sign between me and you' (v. 19b, 20). These allusions to the Sinai law, like the initial commands prohibiting idolatry mentioned above, close with a reference to the divine name: 'so that they might know that I YHWH sanctify them' (v. 12) and 'so that you may know that I am YHWH your God' (v. 20).

'Life' and 'death' underscore the binary of idolatry versus Sinai. For each generation, observing the idolatrous laws amounts to 'rebellion' - failure to observe YHWH's lifeaffirming laws, subjecting them to death. In verse 8 , YHWH states concerning the first generation in Egypt, 'they rebelled against me', specifically by not having 'cast away the detestable things their eyes feasted on' and they did not 'forsake the idols of Egypt'. Likewise, of that same generation in the wilderness and of the second generation that followed, YHWH declares '[they] rebelled against me' by not observing 'my statutes [and] my ordinances, by whose observance everyone shall live' and for having 'profaned my Sabbaths' (v. 13, 21). With each iteration, the zero sum equation is completed in YHWH's thoughts of wiping out the people completely, but is broken off by reasoning that reflects the appeal of prophetic intercession (v. 8b-9, 13b-14, 21b-22). Instead, for each generation YHWH announces their punishment with a sworn oath the first generation would die in the wilderness (v. 15), and the second generation (that would enter the land) would eventually be scattered (v. 23).

\section{Conflation of time}

Thirdly, the history is no mere recounting of past events, but a genealogy of the present condition of the elders. The oracle connects the two generations with the present through verses 23-24, which continue the pattern and extend it. The punishment of scattering announced for the second generation in verse 23 effectively functions to collapse the subsequent history that follows the second generation, thereby connecting the second generation directly to the present generation in exile. The summary statement in verse 24 , 'their eyes were set on their ancestors' idols', equates the violation of ordinances, statutes and Sabbaths with idolatry, and hearkens back to the summary of the very first generation in verse 16: 'their heart went after their idols'. What was true of the first generation was true of the second and remains true today. Thus, verses $27-31$ - a section which does not follow the pattern established in the two exemplary generations but speaks directly of the present generation - serves to clarify the history. 


\section{Idolatry and Sinai: A fine line}

Fourthly, the oracle presents the 'bad statutes' in verses 25-26 as the denouement of the history and, as such, they serve to cloud what had to this point been clear by revealing a fine line that distinguishes idolatrous statutes from the Sinai statutes. The structural trajectory of the oracle connects the problematic laws with both the commandments proscribing idolatry and the expression of the law at Sinai. The two statements 'I gave them statutes that were not good and ordinances by which they could not live' and 'I defiled them through their very gifts, in their offering up all their firstborn' parallel the two-part statements proscribing idolatry issued to the first and second generations described above. For the first generation: 'cast away the detestable things your eyes feast on' and 'Do not defile yourselves with the idols of Egypt (v. 7)'; and for the second generation: 'Do not follow the statutes of your parents, nor observe their ordinances' and '[do not] defile yourselves with their idols' (v. 18). The connection between the two sets is especially clear in the use of the masculine plural חקים for the 'not good' statutes given by YHWH (v. 25) and for the statutes of the parents (v. 18), given that elsewhere throughout the oracle the feminine form nקות describes YHWH's laws. Moreover, YHWH's act of giving of the 'not good' laws that were unable to confer life, 'I gave them statutes that were not good and ordinances by which they could not live', clearly subverts the language of the life-giving revelation at Sinai 'I gave them my statutes and my ordinances by whose observance everyone shall live ... I gave them my sabbaths' (v. 11-12). The reference to defilement in the command regarding idolatry 'Do not defile yourselves' (v. 7, 18) pertains to idolatry and is invoked in YHWH's statement 'I defiled them' (v. 26), as verse 31 clarifies. The shift from the command regarding idolatry 'Do not defile yourselves (v. 7, 18) to the statement 'I defiled them' also contains a shift in the agent of defilement from the people to YHWH. The defiling is specified as rendered 'through their gifts (מתנות) in offering up [literally translated: 'making pass over'] everything that opens the womb (בהעביר כל־פטר רחם) - a technical reference to the law of the firstborn. ${ }^{7}$ This reference is further clarified at the end of the oracle (v. 31) in the direct speech to the elders 'when you offer your gifts (מתנות) by making your children pass over the fire (בהעביר בניכם באשות) you defile yourselves with idols to this day (עדי־היום נטמאים לכל־גלוליכם באשם בעיכם)'.

The structure of the oracle reveals that the dual statement of justification in verse 26, 'in order that I might horrify them, so that they might know that I am $\mathrm{YHWH}^{\prime}$, stands in relation to the 'not good' laws much like similar expressions of the name associated with previous references to law. It is noted above how the proclamation of the divine name immediately follows the two-part statement proscribing idolatry issued to

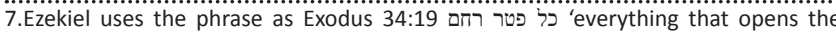
womb' Some commentators have pointed out that verse 26 makes no explicit womb. Some commentators have pointed out that verse 26 makes no explicit mention of human sacrifice and, further, that there is no biblical or archaeologica evidence that the law of the firstborn was practiced regularly as child sacrifice to YHWH (Greenberg 1983:369-370). Hahn and Bergsma (2004) suggest that the phrase everything that opens the womb is a reference to animal sacrifice and explain it as a priestly reaction to a Deuteronomic treatment of sacrifice. For a recent treatment of key issues on the question of child sacrifice see Stavrakopoulou (2004). each generation: 'I am YHWH your God' (v. 7) and 'I YHWH am your God' (v. 19a). It is also noted that the allusions to the Sinai law close with a similar reference to the divine name: 'so that they might know that I YHWH sanctify them' (v. 12) and 'so that you may know that I am YHWH your God' (v. 20). Thus, the justification for YHWH's act of giving 'not good' laws and defiling the people is in some way a subversion of the covenant relation. Inasmuch as verse 31 clarifies verse 26 , it also clarifies the broader frame of the oracle: the 'not good' laws, the law of the firstborn, child sacrifice, idolatry, this present state of affairs explains YHWH's refusal to be consulted.

The 'not good' laws therefore not only summarise, but embody all of the statues and ordinances presented in the history. Moreover, the law of the firstborn in its explicit connection with the practice of child sacrifice and idolatry serves to clarify 'not good' laws. Finally, the 'not good' laws not only explain YHWH's refusal, they constitute the nonconsultation.

\section{'Not good' laws and the fine line between idolatry and Sinai}

The fine line between idolatrous statutes and ordinances, and divine statutes and ordinances serves to problematise the symbolic order - what Lacan modeled as the 'big Other.' The distinction on which the fine line is based is a matter of judgment, perception or attitude (in the phenomenological sense). Judgment and perception are important themes in Ezekiel beyond the oracle of chapter 20 (e.g. Ezk 3:4-6, 10; 33:32).

\section{'Not Good' law and the symbolic order}

The structure of the oracle frames statutes and ordinances as tradition - as that which is passed down and into which a people is born. As tradition the laws function to reveal a fundamental problem of agency with respect to the social field. The ostensive thread running through the oracle is judgment upon the elders for the 'abominations of their ancestors', and it is precisely this theme that is developed through the concept of law in statutes and ordinances. As we have seen, the history collapses time, rendering the first two generations paradigmatic and conflating the second generation with the present generation, and thereby revealing the actions of the past in the actions of the present, who stand as the responsible agents. Further, although the history of Ezekiel 20 presents generational groups, it also places emphasis on the individual, made clear in the initial command of verse 7 that 'each person' cast away (איש...השליכו) the detestable things of the eyes. The statutes and ordinances of the ancestors, like the 'not good' statutes and ordinances of YHWH hold sway over conduct. The self-defiling acts of the elders (v. 31) that arise from the statutes and ordinances of tradition are explained as YHWH's act of defiling by giving 'not good' laws. Thus, agency is maintained as a central problematic in the oracle, both through YHWH's act of giving 
'not good' laws and through YHWH's act of defiling the people, of bringing about their self-defilement. In this way, the 'not good' laws, by virtue of their structural associations with statutes and ordinances of the ancestors and by virtue of their status as given by $\mathrm{YHWH}$, occupy the position of the symbolic order. The oracle places statutes and ordinances in the position of the social field, setting them up as the site of the 'eruption of subjective contingency'.

\section{Prophetic revelation and misrecognition}

Approaching the statutes and ordinances in terms of the symbolic order allows us to make sense of the thin line between the life-affirming statutes and ordinances of Sinai and the life-denying statutes and ordinances of idolatry. The framing device of the failed consultation reveals the oracle itself to be the consultation (Greenberg 1983:252-253). The text thus invites us to consider the 'not good' laws as integral to the judgment of YHWH against the elders in the refusal to be consulted. We encounter a similar set of ideas in Ezekiel 14:1-11. In both cases the elders come to Ezekiel and YHWH refuses to be consulted because of idolatry (Ezk 20:31; 14:2-3). In both cases the answer includes a revelation of misdirection: in the 'not good' statutes and ordinances (Ezk 20:25) and in the deceived prophet (14:9-10). In both cases, idolatry (and with it, death) is the consequence of idolatry (Chisholm 1998:25; cf. Greenberg 1983:253). ${ }^{8}$ Similarly, Greenberg (1983:253), comparing the two passages, asserts "The "idols" in the people's thoughts and "before their faces" must be a rubric for an unregenerate state of mind.'

What we encounter in YHWH's admission of having deceived the prophet (Ezk 14:9) and of having given 'not good' laws (20:25-26) takes on a different form in related statements of Jeremiah in which YHWH explicitly disavows having commanded child sacrifice (Jr 7:31; 19:5; 32:35). Behind the social problem of 'prophetic conflict' lies the epistemological problem summarised in Deuteronomy 18:9-22, which contrasts 'abominable' cultural practices of the nations with the prophet like Moses, in the question (immediately following notice that the prophet who speaks an unauthorised word in YHWH's name shall die) 'How can we recognize a word that the LORD has not spoken?' However, the paradoxical presentation of statutes and ordinances, set within the frame of a failed consultation and viewed in light of the disavowals of YHWH in Jeremiah (cf. Bewer 1953:160), suggest the epistemological problem to be more phenomenological. That is, what is true of the lifeaffirming statutes and ordinances of Sinai, is true also of the life-denying statutes and ordinances of idolatry - they share a fundamental property with respect to language akin to what Žižek (2008) writes of ideology, wherein we discover:

[...] the paradox of a being which can reproduce itself only in so far as it is misrecognized and overlooked: the moment we see it 'as it really is', this being dissolves itself into nothingness or, more precisely, it changes into another kind of reality. [...] That is why we must avoid the simple metaphors of demasking, of throwing away the veils which are supposed to hide the naked reality. (p. 25)

Moreover, the prophet occupies a crucial position with respect to the symbolic order (Ezk 3:17-21; 33:1-9) and how it is mediated and faces the unenviable task of using the symbolic order to point to and critique itself. The task seems to fall under what Žižek (1994), in addressing the problematic of ideology, calls the 'antinomy of critico-ideological reason':

[...] ideology is not all; it is possible to assume a place that enables us to maintain a distance from it, but this place from which one can denounce ideology must remain empty. It cannot be occupied by any positively determined reality - the moment we yield to this temptation, we are back in ideology. (p. 17)

My point is not to equate in simple terms the life-affirming statutes and ordinances of Sinai with ideology. Rather, it is to point to the property they share.

\section{'Child Sacrifice' and the liberation of the subject}

Some commentators have interpreted the passage as reflecting the kind of divine testing described in Deuteronomy 13:1-5. The law of the firstborn alluded to in Ezekiel 20:26 has its origins in the constitutive act of Israel's deliverance. ${ }^{9}$ The structure of the oracle, however, equates the law of the firstborn (v. 26) with child sacrifice (v. 31) and death (v. 25). Moreover, the concluding section of the oracle equates child sacrifice with idolatry (v. 31), which runs through the entire oracle. ${ }^{10}$ George Heider $(1988: 722,724)$ argues that the passage connects the law of the firstborn with death of the Egyptian firstborn in a way that constitutes 'a frightful turning of a plague once visited on an ancient foe of Yahweh against Israel'. Robert Carroll (1979:199) considers the 'not good' laws a primitive form of aversion therapy.

The stated rationale 'that I might horrify them' (v. 26) invokes obvious trauma that lies behind child sacrifice. ${ }^{11}$ We see it in the narrative complex of Genesis - Kings in the irony of Jephthah's vow (Jdg 11:29-40). In a very different way, it manifests in the efficacy of Mesha's sacrifice (2 Ki 3). The trauma is, however, the logical key to its efficacy. Nowhere is this more evident than in the account of the Aqeda in Genesis 22. As Jon Levenson (1993) points out:

Abraham will have his multitudes of descendants only because he was willing to sacrifice the son who is destined to beget them. Any construal of the text that minimizes that willingness misses the point. (p. 13)

To this we may compare the image of detachment suggested of the Levites, who in the face of idolatry willingly slay son

9.The rationale given for the law of the firstborn in Exodus 13:15 explicitly states that it commemorates the death of the firstborn following the stubborn refusal of Pharaoh to allow the people to leave (cf. Ex 4:22).

10.This same equation is made in Ezekiel 16:20-21, 36 and 23:37, 39.

11.Cf. the severe emotional trauma experienced by the Egyptians (Ex 11:6-8; 12:30; e.g. Mi 6:6; cf. Jr 6:26; Zch 12:10). 
and brother, an act which sets them apart for the service of $\mathrm{YHWH}$ and to receive a blessing (Ex 32:26-29; cf. Dt $13: 6-10 ; 33: 9)$.

The attitude of detachment behind child sacrifice embodies the kind of radical break from the symbolic order that Žižek asserts as foundational to the 'ethical act'. As Russell Grigg (2008) explains:

This act, which is an 'act in the Lacanian sense', is an act of 'withdrawal by means of which we renounce renunciation itself, [and become] aware of the fact that we have nothing to lose in a loss.' In this act the agent is radically transformed: 'After an act, I'm literally 'not the same as before.' The subject is 'annihilated and subsequently reborn'; 'the act involves a kind of ... aphanisis of the subject.' This aphanasis occurs because of the cut with all prior symbolic moorings by means of which the subject has acquired all previous identity. A new symbolic network entails the 'death' of the old and the 'birth' of a new subject. (p. 122)

The law of the firstborn is emblematic of the attitude one must have with respect to the symbolic order, a proper, 'lifeaffirming' attitude of detachment.

In conclusion the subtle subversion of the covenant relation in the recognition formula can be recalled. Jacqueline Lapsley (2000:93), who finds the reference to idols to bespeak the people's 'fundamental inability to obey Yahweh', suggests the problem lies in the 'moral equipment' of the people (Lapsley 2000:104-105). This problem is correctable only through an act of divine intervention in the new heart - moral equipment that provides for acquiring the knowledge of $\mathrm{YHWH}$, which, according to Lapsley (2000):

[...] concerns at heart an orientation to existence that shapes human identity and action. Thus, when the people receive this knowledge of Yahweh they will be changed at the core of their own identity in addition to possessing a new understanding of Yahweh; knowledge of God implies knowledge of self. As a consequence of this radically new identity, the people will be empowered to choose morally appropriate actions and carry them out. (p. 125, [author's italics])

\section{Conclusion}

We have seen that the clear binary of idolatry and YHWH's laws, underscored by the binary of life and death, is nonetheless governed by an exceedingly fine line, presented most clearly in the bad laws that appear to occupy the same discursive space as the statutes and ordinances of the ancestors and are tantamount to idolatry (v. 31; cf. Ps. 106:34-39). What is at stake in the choice is life and death. The oracle places statutes and ordinances in the position of the symbolic order, setting them up as the site of the eruption of subjective contingency. Idolatry, as a condition of the heart, suggests the often hidden inferential basis of action through the (ir)rational choice of which 'law' to follow, further revealing the distinction to be not material, but operational. The 'not good' laws of Ezekiel 20:25-26 are emblematic of the law in the most fundamental human sense - as the symbolic order. The cautionary note that Žižek (1994:17) offers concerning 'the trap of sliding into ideology under the guise of stepping out of it' befits Ezekiel's treatment of idolatry.

The fundamental problem inscribed in the text also presents an opportunity for thinking about 'biblical values' within the context of broader society. To return to the title of Žižek's article, 'How the Non-duped Err' (1990) takes up the symbolic order in its aspect as authority, which Lacan, seeing it as homologous to the paternal relation, placed under the designation le nom du pere [the name of the father] - a designation he immediately subverted as les non dupes err [the non-duped err], recognising the fictive nature of the symbolic order and pointing to the vital importance of the domain of pure symbolic authority. Ultimately, those who are not fooled, that is 'those who do not let themselves be caught in the symbolic deception/fiction ... are the ones who err most'. Such cynics miss what Žižek (1999:390) calls 'the efficiency of the symbolic fiction, the way this fiction structures our experience of reality'. What does this suggest for contextual reading as a multi-racial, multi-ethnic project? The point here is that developing new paradigms for engaging the Bible forcefully and effectively are increasingly important in view of the extent to which the text plays a role in social and political discourse.

We would be mistaken to suppose that a single paradigm is sufficient to ground a project of contextual reading. Multicultural, multi-ethnic society highlights the peril of projects within the academy that privilege any particular group without orienting each particular discursive structure within a broader framework that seeks to address the conditions of discourse - the processes - that make communication possible. To this end, and in light of the study, three suggestions are offered. Firstly, rather than attempting to efface or promote difference, the particular must instead be tended to as a relational whole (Rivera 2009:313-329). Secondly, in doing so, we must also give attention to the consequences of fixing difference within the categories of our literary and intellectual canons in ways that are not open to dialogue. Finally, we must seek ways to dialogue around complex subjectivity, both prior to and within our readings, ways that are responsive to the changing contours of subjectivity with respect to the other. A suggestive project is found in West 2005:23-35. Other examples are found in the model of Habermas' project of communicative rationality, by which disparate voices of the academy and society at large anticipate and explore overlapping figurations of human nature and activity in the interest of civil society, and in the dialogism of Gavin Flood (1999) in which 'a self [...] only exists in relation to the other within the linguistic community' and 'self and other are actively co-productive and demand an ethical response from the other'. Moreover, it entails the self's ability to act and to affect the other and the other's ability to affect the self (Flood 1999:218). 'In this sense dialogism is not relativism and polyphony entails, on the contrary, communication and contact across human divides' (Flood 1999:218). 
In light of the text, the suggestion could be made that the prospects of multi-cultural, multi-ethnic reading - its successes and failures - ride on no less than establishing and maintaining a keen awareness of subjectivity in its complexity and how such awareness can illuminate the perils of identity and idolatry that attend acts of discerning moral authority in divine law. A program of contextual biblical study ideally would be explicit in formulating appropriate methods and controls to help guide and reflect upon this aspect of the reading process. In this way conditions can be created for vibrant visions that both see liberation and recognise it for what it is.

\section{Acknowledgements Competing interests}

The author declares that he had no financial or personal relationship(s) that may have inappropriately influenced him in writing this article.

\section{References}

Allen, L., 1990, Ezekiel 20-48, Word Books, Dallas, TX.

Allen, L., 1992, 'The structuring of Ezekiel's revisionist history lesson (Ezekiel 20:2-31)' Catholic Biblical Quarterly 54, 448-462.

Allen, L., 1994, Ezekiel 1-19, Word Books, Dallas, TX.

Bewer, J.A., 1953, 'Textual and exegetical notes on the book of Ezekiel', Journal of Biblical Literature 72, 159-161. http://dx.doi.org/10.2307/3262056

Blenkinsopp, J., 1990, Ezekiel, John Knox Press, Kentucky.

Block, D., 1997, Ezekiel: Chapters 1-24, Eerdmans, Grand Rapids.

Carroll, R.P., 1979, When prophecy failed: cognitive dissonance in the prophetic traditions of the Old Testament, Seabury Press, New York.

Chisholm, R.B., 1998, 'Does God deceive?', Bibliotheca Sacra 155, 11-28.

Dennett, D.C., 1991, Consciousness explained, Little, Brown \& Co., Boston, New York, London.

Elster, J., 1983, Sour grapes: Studies in the subversion of rationality Cambridge University Press, Cambridge, New York. http://dx.doi.org/10.1017/ CBO9781139171694

Flood, G. 1999, Beyond phenomenology: Rethinking the study of religion, Cassell, London, New York.
Greenberg, M. 1983, Ezekiel 1-20: A new translation with introduction and commentary, Doubleday, Garden City, New York.

Grigg, R., 2008, Lacan, language, and philosophy, State University of New York Press, Albany, NY.

Hahn, S.W. \& Bergsma, J.S., 2004, 'What laws were 'not good'? A canonical approach to the theological problem of Ezekiel 20:25-26', Journal of Biblical Literature 123(2), 201-218. http://dx.doi.org/10.2307/3267942

Heider, G.C., 1988, 'A further turn on Ezekiel's baroque twist in Ezek 20:25-26', Journal of Biblical Literature 107(4), 721-724. http://dx.doi.org/10.2307/3267632

Johnston, A., 2008, Žižek's ontology: A transcendental materialist theory of subjectivity, Northwestern University Press, Evanston, IL.

Lapsley, J.E., 2000, Can these bones live? The problem of the moral self in the book of Ezekiel, De Gruyter, Berlin, New York. http://dx.doi.org/10.1515/9783110822977

Levenson, J.D., 1993, The death and resurrection of the beloved son: The transformation of child sacrifice in Judaism and Christianity, Yale University Press, New Haven.

Mein, A. 2001, Ezekiel and the ethics of exile, Oxford University Press, Oxford.

Mol, J., 2009, Collective and individual responsibility: A description of corporate personality in Ezekiel 18 and 20, Brill, Leiden, Boston. http://dx.doi.org/10.1163/ ej.9789004170438.i-287

Patton, C., 1996, 'I myself gave them laws that were not good: Ezekiel 20 and the Exodus traditions', Journal for the Study of the Old Testament 69:73-90. http:// dx.doi.org/10.1177/030908929602106905

Rivera, M.R., 2009, 'Incarnate words: images of god and reading practices', in R. Bailey., T.B. Liew \& F. Segovia, They were all together in one place? Toward minority biblical criticism, pp. 313-329, Society of Biblical Literature, Atlanta.

Rom Shiloni, D., 2005, 'Facing destruction and exile: Inner-biblical exegesis in Jeremiah and Ezekiel', Zeitschrift für die alttestamentliche Wissenschaft 117, 189-205. http://dx.doi.org/10.1515/zatw.2005.117.2.189

Stavrakopoulou, F., 2004, King Manasseh and child sacrifice: Biblical distortions of historical realities, De Gruyter, Berlin. http://dx.doi.org/10.1515/9783110899641

Sugirtharajah, R.S., 2006, Voices from the margin: Interpreting the bible in the third world, Orbis, Maryknoll, New York.

Van der Horst, P.W., 1992, 'Laws that were not good: Ezekiel 20:25 in ancient Judaism and early Christianity', in J.N. Bremmer \& F. García Martínez, Sacred history and sacred texts in early Judaism, pp. 94-118, Kok Pharos Pub, Kampen, Netherlands.

West, G.O., 2005, 'Articulating, owning and mainstreaming local theologies: The contribution of contextual biblical study', Journal of Theology for Southern Africa, $122,23-35$.

Zimmerli, W., 1979, Ezekiel: A commentary on the book of the prophet Ezekiel, chapters 1-24, Fortress Press, Philadelphia.

Žižek, S., 1990, 'How the non-duped err', Qui Parle 4 (1), 1-20.

Žižek, S., 1994, Mapping ideology, Verso, New York, London.

Žižek, S., 1998, 'The Cartesian subject versus the Cartesian theatre', in S. Žižek (ed.), Cogito and unconscious, pp. 247-274, Duke University Press, Durham, NC. http:// dx.doi.org/10.1215/9780822382126-010

Žižek, S., 1999, The ticklish subject: The absent centre of political ontology, Verso, London, New York.

Žižek, S., 2008, The sublime object of ideology, Verso, London, New York. 